\title{
SALINITY IMPLICATIONS OF WASTEWATER IRRIGATION IN THE MUSI RIVER CATCHMENT IN INDIA
}

\author{
Matthew McCartney ${ }^{1}$, Christopher Scott ${ }^{2}$, Jeroen Ensink ${ }^{3}$, BinBin Jiang ${ }^{4}$ and Trent Biggs ${ }^{5}$ \\ ${ }^{1}$ International Water Management Institute, Addis Ababa, Ethiopia \\ ${ }^{2}$ International Water Management Institute, Hyderabad, India. \\ (currently University of Arizona, Tucson, Arizona, USA) \\ ${ }^{3}$ London School of Hygiene and Tropical Medicine, London, UK. \\ ${ }^{4}$ Department of Environmental Engineering, Stanford University, USA. \\ ${ }^{5}$ International Water Management Institute, Hyderabad, India \\ (currently San Diego State University, California, USA) \\ Accepted 7 June 2008
}

\begin{abstract}
As a consequence of increasing urbanization and shortage of good quality water, wastewater irrigation is a growing phenomenon in many arid and semi-arid countries. A common characteristic of wastewater is high salinity, with cities typically adding $200-500 \mathrm{mg} \mathrm{l}^{-1}$ of total dissolved solids compared to the source water supplied to the city. Wastewater from the city of Hyderabad in southern India is discharged to the Musi river. Downstream of the city this water, supplemented with groundwater and runoff captured in small reservoirs, is an important source for irrigation. Comparisons between upstream and downstream monitoring sites, over a distance of $39.7 \mathrm{~km}$, revealed changes in the salinity of the river water. A simple mass-balance model was developed to simulate the observed differences. Results indicate that $94 \%$ of the salt load originates in the city. Downstream salinity increased by about $9 \%$. In fields irrigated with wastewater, soil salinity increased with time with salt retention of approximately $34 \mathrm{~kg} \mathrm{ha}^{-1} \mathrm{y}^{-1}$. This represents approximately $0.1 \%$ of the total salt load applied to the land. In many places the soils have salinity in excess of recommended tolerance levels for rice, once the principal crop, but which is now increasingly being converted to fodder grass.
\end{abstract}

\section{INTRODUCTION}

The disposal of untreated or only partially treated wastewater from cities into rivers and lakes is common in many developing countries (WHO, 2006). Since the construction of city sewerage systems at the beginning of the $20^{\text {th }}$ century, urban sewage has been used in agriculture. As a consequence of rapid urbanization and increasing freshwater scarcity, greater numbers of farmers than ever before are relying on it for irrigation in peri-urban and rural areas downstream of major cities (Scott et al., 2004). Currently, there is no definitive estimate of the total global extent of wastewater irrigation. However, it has been estimated that $80 \%$ of wastewater in developing countries may be used for irrigation (Cooper, 1991) indicating that many millions of hectares may be irrigated with raw or partially diluted wastewater.

The use of wastewater is associated with an increased risk of various infectious diseases as a result of high pathogen and other contaminant concentrations (WHO, 2006). The discharge of untreated or only partially treated wastewater can also have significant environmental impacts, including adverse effects on freshwater biota (Dickens and Graham, 1998). Furthermore, the quality of irrigation water can have a profound impact on crop production (Grattan, 2002). If not managed carefully, the use of wastewater can lead to soil degradation and reduction in yield (Pescod, 1992).

Of particular concern in arid and semi-arid areas are the possible consequences arising from the high salinity of wastewater (both untreated and treated). There is a paucity of information on the ecological impacts of increased salinity in river water. However, it is known that if sufficiently high and prolonged, elevated salinity levels will affect aquatic organisms (Hart et al., 1991; Peterson and Meador, 1994). Furthermore, if carefully managed, moderately saline water can be used to successfully grow crops (Kijne, 2003), but

*Corresponding author's email: M.MCCARTNEY@CGIAR.ORG 
yields can be reduced and the long-term sustainability of irrigation systems undermined if saline water is used inappropriately (James, 1988). In India, some 5.2 million ha of irrigated land (not specifically irrigated with wastewater) have been lost as a consequence of soil salinization (Paroda, 1998). The concern is that wastewater irrigation may result in more rapid salinization and hence degradation of agricultural land.

This paper reports findings from a study investigating the impact of wastewater irrigation from the Musi river downstream of the city of Hyderabad in Andhra Pradesh, India. The primary aim of the water quality component of the study was to ascertain the health impacts (Ensink, 2006). However, electrical conductivity measurements were made and analyzed to assess the impact of the wastewater irrigation on the salinity of the river water and the soil of irrigated fields and to evaluate whether recent declines in rice yield, reported by many farmers, are attributable to soil salinization.

\section{Study area}

Historically, agriculture has been the main source of income and livelihoods in Andhra Pradesh. However, this is changing; in recent years with rapid increases in manufacturing, construction, utilities and service sectors. Between 1960 and 1995, the share of the state's income generated from agriculture was reduced from 59\% to $38 \%$ (James and Robinson, 2001). In the decade to 2001, the population of the city of Hyderabad, and its surrounding urban and peri-urban municipalities, grew by $17.2 \%$ to approximately 6 million, making it the fifth largest, and one of the fastest growing, urban centres in India (UN, 2002). The Musi river, a tributary of the Krishna River, which flows east to the Bay of Bengal, originates in the Anantha Giri Hills, $60 \mathrm{~km}$ west of Hyderabad, and flows through the heart of the city. Mean annual rainfall in the region is approximately $800 \mathrm{~mm}$, falling predominantly in the monsoon months of June to September (Van Roojen et al., 2005).

Two reservoirs, Osman Sagar and Himayat Sagar, constructed on the Musi River and the Musa River (a tributary of the Musi) upstream from Hyderabad have supplied water to Hyderabad from early $20^{\text {th }}$ century. However, since the 1950s the water from these reservoirs has been insufficient to meet the needs of the growing population, and there has been increasing use of groundwater and water pumped from other rivers (Table 1). The most recent addition to the city supply, which commenced in April 2004, is abstraction directly from the Krishna River, upstream of the confluence with the Musi River (Van Rooijen et al., 2005).

There are no dry season releases from the Osman and Himayat dams and except for spillway overflow during heavy rainstorms in the monsoon months, the Musi River ceases to flow upstream of the city. Hence, for most of the year, the flow downstream of Hyderabad is primarily wastewater from the city. The average discharge of wastewater into the Musi River is estimated to be $550,000 \mathrm{~m}^{3}$ $\mathrm{d}^{-1}$ (Ensink, 2006), which equates to $201 \mathrm{Mm}^{3} \mathrm{y}^{-1}$ (i.e., $70 \%$ of the water supplied to the city). The wastewater comprises both domestic and industrial effluent. Although more wastewater treatment plants are planned, it is estimated that currently only $52.8 \mathrm{Mm}^{3}$ (21\% of the wastewater) has any form of treatment prior to disposal. Furthermore, only the smaller of Hyderabad's two treatment plants (treating less than $5 \%$ of the city's wastewater) has the capability for more than primary level treatment (Gerwe, 2004).

Table 1. Sources of water to the city of Hyderabad. ( Source: van Rooijen et al., 2005)

\begin{tabular}{llll}
\hline \multicolumn{1}{c}{ Source } & $\begin{array}{c}\text { Date } \\
\text { commenced }\end{array}$ & Catchment & $\begin{array}{c}\text { Estimated volume of water supplied } \\
\mathbf{2 0 0 4}\left(\mathbf{M ~ m}^{\mathbf{3}}\right)\end{array}$ \\
\hline Osman Sagar & Early 1900s & Musi & 12 \\
Himayat & Early 1900s & Musa & 12 \\
Sagar & & & \\
Manjira River & 1960 & Godavari & 61 \\
Singur River & 1991 & Godavari & 102 \\
Krishna River & 2004 & Krishna & 61 \\
Groundwater & - & - & 41 \\
& & Total & 289 \\
\hline
\end{tabular}


Downstream of Hyderabad, water is diverted into irrigation channels at weirs located every few kilometres along the river. On both sides of the river, the area is criss-crossed by an extensive network of irrigation canals and drainage channels. These are interconnected with small reservoirs, locally known as tanks, forming a complex artificial flow and storage network (Fig. 1). An estimated 10,000 ha, primarily of rice (Oryza sativa) and paragrass (Brachiaria mutica) are irrigated with water from the Musi River (Katta, 1997). Paragrass is perennial and grows well under warm, moist and fertile conditions. It is cultivated for buffalo fodder. Irrigation enables farmers to harvest paragrass throughout the year or to produce two rice crops annually. Furthermore, because the wastewater is high in nutrients, farmers save money by using less fertilizer (Buechler et al., 2002). Utilisation of wastewater in the peri-urban and rural areas downstream of Hyderabad is estimated to support, directly and indirectly, the livelihoods of approximately 150,000 people (Buechler et al., 2003).

In recent years many rice farmers have reported declines in yield and deterioration of grain quality, including taste, texture and shelflife. For example, farmers in the village of Peerzadiguda have observed a $30 \%$ yield reduction in fields irrigated with water from the Musi River. It has been hypothesised that the yield reductions are a consequence of increased salinities (Buechler and Mekala, 2005). In places closer to Hyderabad, many farmers have changed from growing rice to paragrass and it is possible that, because paragrass has a higher salt tolerance, this switch is a farmer adaptation to higher salinities (Buechler and Mekala., 2005). However, it is also possible that there are socio-economic reasons for the switch. These include the fact that paragrass is easy to grow and requires little attention, thereby enabling farmers to focus on other livelihood activities such as working in the city.

\section{METHODS}

Field measurements of total dissolved solids (TDS) and discharge were made along the Musi River in 2004 to determine the impact of urban wastewater discharge and wastewater irrigation on stream water salinity. A mass balance for water and total dissolved solids was determined for a reach of the river from Amberpet Bridge, located close to the edge of the city, to Bhattaguda, located $39.7 \mathrm{~km}$ downstream (sample points I and VIII, respectively in Fig. 1). The model was based on TDS measurements made along the wastewater irrigated corridor (Fig. 1). It was used to determine the impact of evaporative concentration from irrigation on TDS.

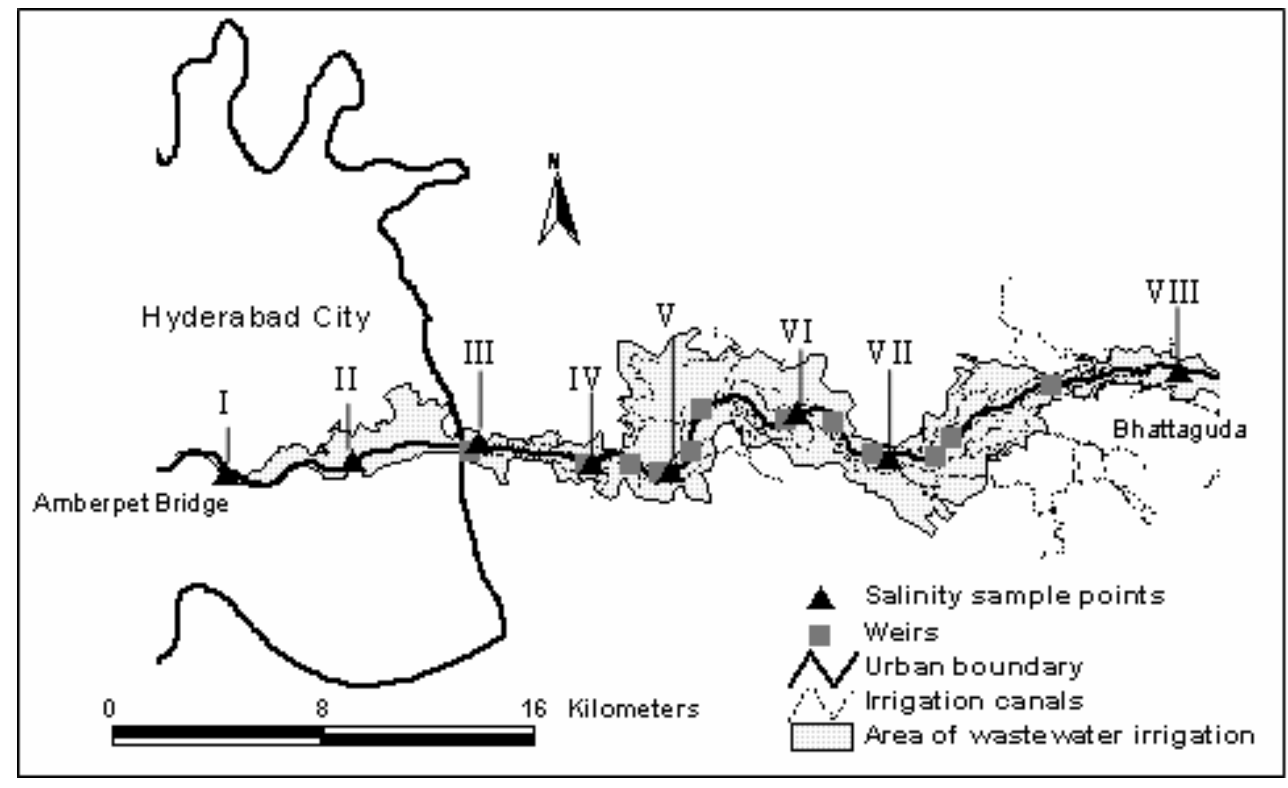

Figure1. Location of irrigation diversion weirs, water quality sampling points, and the main irrigation canals in the wastewater irrigated area of the Musi River catchment. (Sample location names are presented in Table 2.) 


\section{Total dissolved solids}

TDS represents the total quantity of dissolved minerals in water. Since the majority of the material dissolved is ionic, electrical conductivity (EC) is conventionally used as a measure of TDS. In the current study, EC was measured approximately every fortnight from $06^{\text {th }}$ January to $22^{\text {nd }}$ December 2004 at eight locations along the Musi River, from Amberpet Bridge to Bhattaguda (Fig.1 and Table 1). Measurements were made insitu, using a lightweight hand-held meter (Model 85 , YSI, Ohio, USA). EC was converted to TDS using the following relation (Schwab et al., 1993):

$$
\operatorname{TDS}\left(\mathrm{mg} \mathrm{L}^{-1}\right)=\mathrm{EC}\left(\mathrm{dSm}^{-1}\right) \times 670
$$

\section{Water Flow}

The water flow was estimated each fortnight throughout 2004 at Amberpet Bridge. At this location, the channel is approximately $50 \mathrm{~m}$ wide and rocky. Surface velocity was determined by timing the movement of a float (i.e., a plastic bottle three-quarters filled with water) over a distance of $25 \mathrm{~m}$. On most occasions measurements were made at approximately midday or early in the afternoon. A correction factor of 0.7 was applied to surface velocity to derive a depth-averaged velocity (Shaw, 1984). The cross-sectional area of flow was determined from depth measurements made approximately every $5 \mathrm{~m}$ across the channel. The flow was calculated as the product of the velocity and the cross-sectional area. On the basis of these measurements, the annual flow at Amberpet Bridge in 2004 was estimated to be $303 \mathrm{Mm}$ No allowance was made for diurnal variation in the flow, which may arise from changes in sewage discharge. However, it was observed that peak flow occurred earlier in the morning and low flow later at night, indicating that midday is a reasonable approximation of average diurnal flow.

Both partially treated effluent and untreated wastewater from the Amberpet treatment plant, including wastewater from industrial areas of the city, discharge into the Musi downstream of the Amberpet Bridge. The current capacity of the Amberpet sewage treatment plant is $41 \mathrm{Mm}^{3} \mathrm{y}^{-1}$ (Gerwe, 2004).

\section{Irrigation diversions}

In February 2005, the velocity-area method described above was used to estimate the flows diverted into irrigation channels at each of the weirs located between Amberpet Bridge and Bhattaguda (Fig. 1). There are no written records of how diversions vary over the year. However, discussions with local farmers on cultivation practices and, where applicable, operation of the gates (when kept closed or open) on the diversion channels provided insight on the pattern of variation through the year. On this basis monthly diversion values were estimated (Fig. 2).

Table 2. Sampling sites for water quality of Musi River, East Hyderabad.

\begin{tabular}{|c|c|c|c|}
\hline Site & Name & Location & $\begin{array}{l}\text { Distance from centre of } \\
\text { Hyderabad }(\mathbf{k m})\end{array}$ \\
\hline \multirow[t]{2}{*}{$\bar{I}$} & Amberpet & $17.37966^{\circ} \mathrm{N}$ & 0 \\
\hline & Bridge & $78.51661{ }^{\circ} \mathrm{E}$ & \\
\hline \multirow[t]{2}{*}{ II } & Nagole Bridge & $17.38355^{\circ} \mathrm{N}$ & 5.2 \\
\hline & & $78.55843^{\circ} \mathrm{E}$ & \\
\hline \multirow[t]{2}{*}{ III } & Peerzadiguda & $17.38633^{\circ} \mathrm{N}$ & 9.6 \\
\hline & & $78.59850^{\circ} \mathrm{E}$ & \\
\hline \multirow[t]{2}{*}{ IV } & Mutialguda & $17.38267^{\circ} \mathrm{N}$ & 19 \\
\hline & & $78.64267^{\circ} \mathrm{E}$ & \\
\hline \multirow[t]{2}{*}{ V } & Gourvelli & $17.38050^{\circ} \mathrm{N}$ & 17.3 \\
\hline & & $78.66722^{\circ} \mathrm{E}$ & \\
\hline \multirow[t]{2}{*}{ VI } & Korremalla & $17.4000^{\circ} \mathrm{N}$ & 20.0 \\
\hline & & $78.7100^{\circ} \mathrm{E}$ & \\
\hline \multirow[t]{2}{*}{ VII } & Pillaipally & $17.38656^{\circ} \mathrm{N}$ & 27.7 \\
\hline & & $78.73696^{\circ} \mathrm{E}$ & \\
\hline \multirow[t]{2}{*}{ VIII } & Bhattaguda & $17.41462^{\circ} \mathrm{N}$ & 39.7 \\
\hline & & $78.83925^{\circ} \mathrm{E}$ & \\
\hline
\end{tabular}




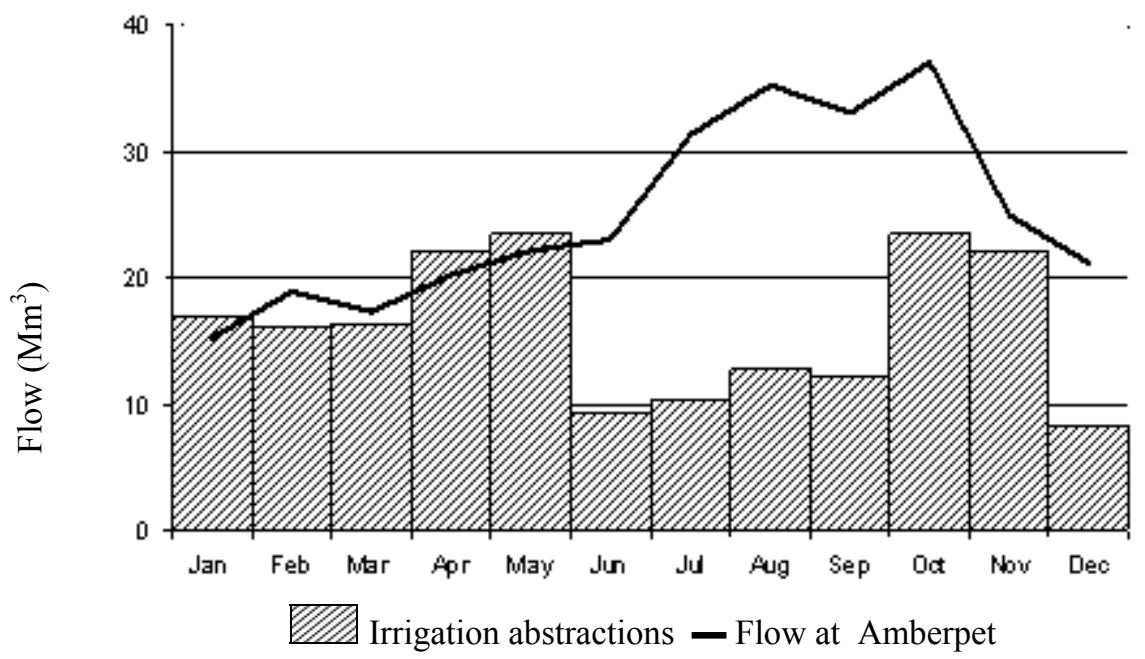

Figure 2: Flow at Amberpet and estimated irrigation diversions from the Musi River, in 2004, to a distance of $39.7 \mathrm{~km}$ downstream of Hyderabad.

The smallest diversions are in June and December when the paddy fields are allowed to dry immediately prior to and following the rice harvest. In January, April and May total diversions were estimated to be slightly higher than total flow at Amberpet. This is possible, since as discussed above, the flow measured at Amberpet does not include urban effluent entering the river downstream and because diversions downstream capture return flows from upstream diversions. Total annual diversions in 2004 were estimated to be $193 \mathrm{Mm}$ For 10,000 ha of irrigated land, this equates to $0.61 \mathrm{l} \mathrm{s}^{-1} \mathrm{ha}^{-1}$ or $1,930 \mathrm{~mm} \mathrm{y}^{-1}$.

Estimates of annual crop water demands, based on net radiation measurements in Hyderabad and the Priestley-Taylor formula (Priestley and Taylor, 1972) were $1,600 \mathrm{~mm}$ for both rice and paragrass. Since rainfall is approximately $800 \mathrm{mmy}^{-1}$, these figures indicate the need for about $800 \mathrm{~mm}$ of irrigation to supply evaporative demand. The difference between $800 \mathrm{~mm} \mathrm{y}^{-1}$ required and the estimated $1,930 \mathrm{~mm} \mathrm{y}^{-1}$ diverted can be attributed to both transmission losses in the system and the need to maintain ponded conditions for rice cultivation.

\section{Mass balance}

A simple mass balance model was developed to simulate the observed patterns of TDS along the river (Fig. 3). For each river reach, between sampling points, the water balance over a given time interval is:

$$
\mathrm{Q}_{\text {in }}+\mathrm{Q}_{\mathrm{r}}+\mathrm{Q}_{\mathrm{u}}=\mathrm{Q}_{\text {out }}+\mathrm{Q}_{\mathrm{i}}+\mathrm{Q}_{\mathrm{bd}}
$$

Where:

$Q_{\text {in }}$ is the volume of inflow to the reach $\mathrm{Q}_{\mathrm{r}}$ is the volume of irrigation return flow (both surface and groundwater)

$\mathrm{Q}_{\mathrm{u}}$ is the volume of upslope "rural" water mixing with the irrigation return flow

$\mathrm{Q}_{\text {out }}$ is the volume of outflow from the reach $\mathrm{Q}_{\mathrm{i}}$ is the volume of water diverted to irrigation from the reach

$\mathrm{Q}_{\mathrm{bd}}$ is the volume of drainage diverted to downstream fields

Groundwater contributions to base flow from outside the irrigated area are considered negligible due to regionally lowered water tables resulting from excessive groundwater pumping to meet urban and agricultural demand. This assumption is supported by lack of flow in the Musi River during the post-monsoon season upstream of the city. The river bed is also granitic bedrock, and aquifers in the area are typically hard-rock aquifers with limited transmissivity. The salt balance of each reach is derived from the water balance by multiplying each component by its salt concentration:

$\mathrm{Q}_{\text {in }} \mathrm{C}_{\text {in }}=\mathrm{Q}_{\text {out }} \mathrm{C}_{\text {out }}+\mathrm{Q}_{\mathrm{i}} \mathrm{C}_{\mathrm{i}}+\mathrm{Q}_{\mathrm{bd}} \mathrm{C}_{\mathrm{bd}}-\mathrm{Q}_{\mathrm{r}} \mathrm{C}_{\mathrm{r}}-\mathrm{Q}_{\mathrm{u}} \mathrm{C}_{\mathrm{u}} \pm \Delta \mathrm{S}$

Where:

$\mathrm{C}_{\text {in }}$ is the salinity of inflow to the reach

$\mathrm{C}_{\text {out }}$ is the salinity of the water flowing from the reach

$\mathrm{C}_{\mathrm{i}}$ is the salinity of the water diverted for irrigation $\mathrm{C}_{\mathrm{bd}}$ is the salinity of the drainage water diverted to downstream fields

$\mathrm{C}_{\mathrm{r}}$ is the salinity of the irrigation return flow 
$\mathrm{C}_{\mathrm{u}}$ is the salinity of the upslope rural water mixing with the irrigation return flow

$\Delta \mathrm{S}$ is retention or release of salts from soils and groundwater

If it assumed that salt retention in the soils is negligible (i.e. $\Delta \mathrm{S}=0$ ), $\mathrm{Q}_{\mathrm{r}}$ and $\mathrm{C}_{\mathrm{r}}$ are functions of the irrigation water diverted from the river (i.e. $\mathrm{Q}_{\mathrm{i}}$ and $\mathrm{C}_{\mathrm{i}}$ ) and the inflow of water draining from upstream fields (i.e. $\mathrm{Q}_{\mathrm{bu}}$ and $\mathrm{C}_{\mathrm{bu}}$ ) respectively and are dependent only on the irrigation efficiency, eff. Thus:

$$
\begin{aligned}
& \mathrm{Q}_{\mathrm{r}}=\left(\mathrm{Q}_{\mathrm{i}}+\mathrm{Q}_{\mathrm{bu}}\right)(1-\mathrm{eff}) \\
& \quad \text { and } \\
& \mathrm{C}_{\mathrm{r}}=\left(\left(\mathrm{Q}_{\mathrm{i}} \mathrm{C}_{\mathrm{i}}+\mathrm{Q}_{\mathrm{bu}} \mathrm{C}_{\mathrm{bu}}\right) /\left(\mathrm{Q}_{\mathrm{i}}+\mathrm{Q}_{\mathrm{bu}}\right)\right) /(1-\mathrm{eff})
\end{aligned}
$$

Where:

eff is the classical irrigation efficiency, at the level of the irrigation system, expressed as a fraction (i.e., the ratio of water evapotranspired to the amount diverted).

There have been no studies to determine local efficiency and the lack of a measurement downstream of Amberpet prevents determination of an irrigation efficiency for the Musi River corridor. Based on observations of local surface irrigation practices for rice and studies conducted in similar situations (Gosain et al., 2005), for the purpose of the simulation, efficiency was assumed to be 0.3 during the dry season, when potential evaporation is greatest and scarcity means farmers are likely to be constrained in water use, and just 0.15 during the monsoon, when water use is less restricted.

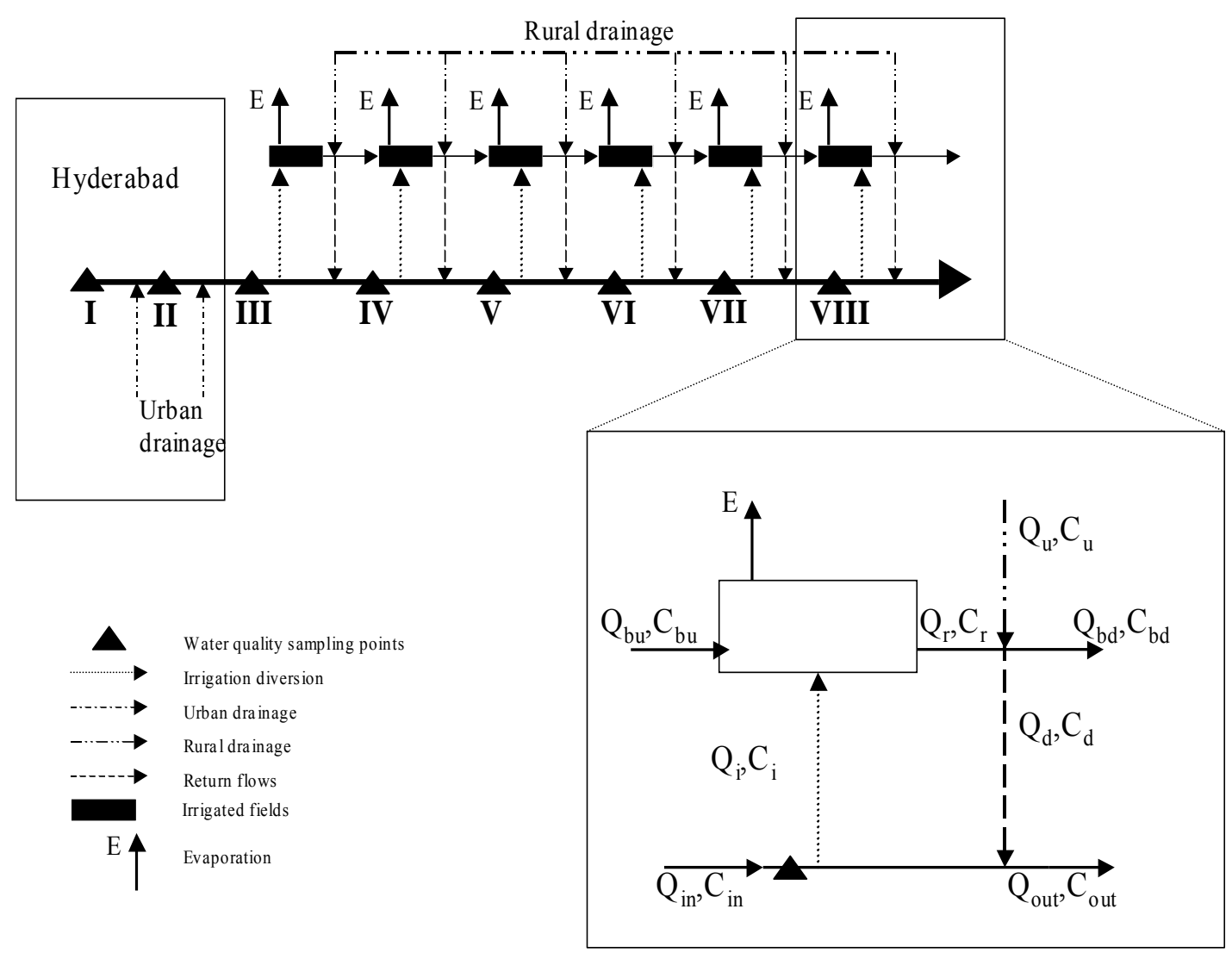

Figure 3. Conceptual model of salt and water budgets along the Musi River, downstream of Hyderabad. (Terms defined in the text) 


\section{Model Application}

The model was used to calculate the water and salt fluxes necessary to simulate the longitudinal salinity profile observed in the river. The model was used with the annual mean data as well as the data for April and August, the months in which river salinities were the highest and lowest respectively.

Several assumptions were made in applying the model. First, that downstream of the city changes in salinity arose primarily as a consequence of irrigation return flows and not from other point or non-point sources. This assumption was justified by the rural nature of the area and the lack of industry. Second, that in each reach, $20 \%$ of irrigation drainage did not flow back to the river, but was diverted to downstream fields (i.e., in equation $1, \mathrm{Q}_{\mathrm{bd}}=0.2 \mathrm{Q}_{\mathrm{r}}$ and in equation $2, \mathrm{C}_{\mathrm{bd}}=\mathrm{C}_{\mathrm{r}}$ ). This meant $20 \%$ of the drainage from reach 7 returned to the river downstream of Bhattaguda by-passing sample point VIII. This was an arbitrary assumption, but reflects the fact that not all diverted water returns to the river in the reach from which it is abstracted. No measurements have been made to confirm this assumption.

The lack of TDS measurements in urban drainage entering the river downstream of Amberpet and also in rural runoff unaffected by wastewater meant it was also necessary to make assumptions about the salinity of these waters. For both waters, TDS was assumed to be greatest in the dry season when evaporation is high and, since there is no rain, the salinity of urban sewage effluent will not be "diluted" with low salinity storm runoff. TDS of wastewater was assumed to be $4000 \mathrm{mg} \mathrm{l}^{-1}$ in the dry season and $2000 \mathrm{mg} \mathrm{l}^{-1}$ in the wet season. TDS of the rural runoff was assumed to be $400 \mathrm{mg} \mathrm{l}^{-1}$ in the dry season and $200 \mathrm{mg} \mathrm{l}^{-1}$ in the wet season.

\section{RESULTS}

\section{River water salinity}

The measurements made show an increase in TDS with distance to approximately $10 \mathrm{~km}$ downstream of Amberpet Bridge, the edge of the urban area (Fig. 4). This increase can be attributed to inflow of saline municipal and industrial discharges. Further downstream, TDS decreased slightly to a distance of approximately $20 \mathrm{~km}$. This indicates that water draining into the river has lower salt concentrations than the river water, suggesting that irrigation return flows are negligible over these reaches and salinity is reduced by inflows of low TDS rural runoff. Between $20 \mathrm{~km}$ and $39.7 \mathrm{~km}$ an increase in TDS was consistently observed over the monitoring periods, indicating inflow of saline water.

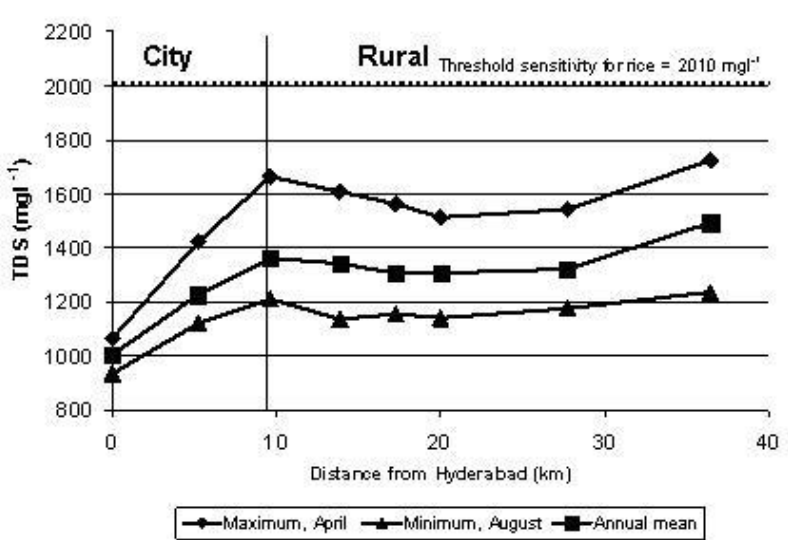

\begin{tabular}{|l|l|l|l|}
\hline \multirow{2}{*}{ Location } & \multicolumn{3}{|c|}{ Average TDS (mg L ${ }^{-1}$ ) } \\
\cline { 2 - 4 } & April & August & Annual \\
\hline I & 1064 & 934 & 1004 \\
\hline II & 1421 & 1122 & 1228 \\
\hline III & 1662 & 1213 & 1361 \\
\hline IV & 1609 & 1135 & 1342 \\
\hline V & 1562 & 1155 & 1306 \\
\hline VI & 1513 & 1141 & 1306 \\
\hline VII & 1542 & 1174 & 1323 \\
\hline VIII & 1721 & 1236 & 1494 \\
\hline
\end{tabular}

Figure 4. Variation in total dissolved solids, TDS, in the Musi River, downstream of Hyderabad. 
Paddy rice, which is classified as moderately sensitive to salt, has a salinity threshold (i.e. the salinity above which yield is reduced) of water in the root zone (while the plants are submerged) of about $0 \mathrm{dS} \mathrm{m}^{-1}$ (i.e. $2010 \mathrm{mg} \mathrm{l}^{-1}$ ) (Hoffman et al., 1981; Tanji and Kielen, 2002). At all locations, the TDS of the river water is well below this threshold. However, accumulation of salts in the soil profile is likely to have an impact on rice production, as discussed below. There do not appear to be any published data on the threshold sensitivity of paragrass. However, many grass species have salinity thresholds that are greater than that for rice. For example, harding grass (Phalaris aquatica), perennial rye grass (Lolium perenne), and wheatgrass (Triticum aestivum) have soil water threshold tolerances of $4.6 \mathrm{dS} \mathrm{m}^{-1}$, $5.6 \mathrm{dS} \mathrm{m}^{-1}$, and $7.5 \mathrm{dS} \mathrm{m}^{-1}$, respectively (Tanji and Kielen, 2002).

Table 3 summarizes the simulated water and salt fluxes for the whole year and for the months of August and April. The assumptions pertaining to the TDS of the wastewater and the rural drainage are shown. It is estimated that in 2004, $64 \mathrm{Mm}^{3}$ of wastewater, both treated at Amberpet sewage treatment plant and that by-passing it, discharged into the river downstream of Amberpet Bridge. Hence, total annual flow from the city was estimated to be $367 \mathrm{Mm}$ This is greater than the average annual wastewater discharge of $201 \mathrm{Mm}^{3}$ (Ensink, 2006) but it includes storm runoff generated within the city as well as monsoon flows from the Osman Sagar and Himayat Sagar reservoirs. Of this, it is estimated that 53\% (i.e.
$193 \mathrm{Mm}^{3}$ ) is diverted for irrigation. Based on the efficiency estimates described above, $44 \mathrm{Mm}^{3}$ of the diverted water is evaporated and $2.5 \mathrm{Mm}^{3}$ bypasses Bhattaguda.

\section{Soil salinity}

The total annual salt load of water from the city is estimated to be $497,000 \mathrm{t}$, and the average annual salt load in wastewater irrigation to the land amounts to approximately $256,000 \mathrm{t}$. In contrast to the salinity of the river, soil salinity decreases with increasing distance from the city. In fields in the vicinity of Peerzadiguda (Table 2) soil salinity, averages $10 \mathrm{dSm}^{-1}$ which equates to approximately 2,081 $\mathrm{kgha}^{-1}$, assuming a bulk density of 1.3 and soil depth of $10 \mathrm{~cm}$ (about the depth of the root zone and depth over which soil samples were obtained). In the vicinity of Bhattaguda, soil salinity averages $3 \mathrm{dSm}^{-1}$ (661 $\left.\mathrm{kgha}^{-1}\right)$. These values compare to $1 \mathrm{dSm}^{-1}$ (214 $\mathrm{kgha}^{-1}$ ) in an area never irrigated with wastewater. The fields in the vicinity of Peerzadiguda have been irrigated with wastewater for longer than those further from the city. Consequently, these data indicate an increase in soil salinity over time. The difference in salinity between areas irrigated with wastewater and those not, in conjunction with an estimate of the approximate number of years for which wastewater irrigation has been undertaken (40 and 20 years for Peerzadiguda and Bhattaguda respectively), indicates an average rate of accumulation of approximately $34 \mathrm{~kg} \mathrm{ha}^{-1} \mathrm{y}^{-1}$ over 10,000 ha. This corresponds to 340 ty $^{-1}$ which represent just $0.1 \%$ of the total salts applied to the irrigation water.

Table 3. Estimated water and salt fluxes between Amberpet and Bhattaguda

\begin{tabular}{|c|c|c|c|c|c|c|}
\hline \multirow[b]{2}{*}{ Assumptions } & \multicolumn{2}{|c|}{ April } & \multicolumn{2}{|c|}{ August } & \multicolumn{2}{|c|}{ Annual } \\
\hline & $\begin{array}{l}\text { TDS wa } \\
=4000 \mathrm{n} \\
\text { TDS rur } \\
=400 \mathrm{~m} \\
\text { Eff }=0.3\end{array}$ & $\begin{array}{l}L^{-1} \\
\text { runoffer } \\
L^{-1}\end{array}$ & $\begin{array}{l}\text { TDS was } \\
=2000 \mathrm{n} \\
\text { TDS rur } \\
=200 \mathrm{~m} \\
\mathrm{Eff}=0.1\end{array}$ & $\begin{array}{l}\text { water } \\
\mathrm{L}^{-1} \\
\text { runoff } \\
-1\end{array}$ & $\begin{array}{l}\text { TDS wi } \\
=3000 \\
\text { TDS ru } \\
=300 \mathrm{n} \\
\text { Eff }=0.2\end{array}$ & $\begin{array}{l}\text { ewater } \\
\mathrm{L}^{-1} \\
\text { runoff } \\
\mathrm{L}^{-1}\end{array}$ \\
\hline & $\begin{array}{l}\text { Water } \\
\left(\mathrm{Mm}^{3}\right)\end{array}$ & $\begin{array}{c}\text { Salt } \\
\left(10^{3} \text { tons }\right)\end{array}$ & $\begin{array}{l}\text { Water } \\
\left(\mathrm{Mm}^{3}\right)\end{array}$ & $\begin{array}{c}\text { Salt } \\
\left(10^{3} \text { tons }\right)\end{array}$ & $\begin{array}{l}\text { Water } \\
\left(\mathrm{Mm}^{3}\right)\end{array}$ & $\begin{array}{c}\text { Salt } \\
\left(10^{3} \text { tons }\right)\end{array}$ \\
\hline Inflow & 20 & 22 & 35 & 33 & 303 & 305 \\
\hline Urban drainage & 5 & 21 & 13 & 25 & 64 & 192 \\
\hline $\begin{array}{l}\text { Irrigation } \\
\text { diverted }\end{array}$ & 22 & 35 & 13 & 15 & 193 & 256 \\
\hline Irrigation return & 15 & 34 & 11 & 15 & 149 & 214 \\
\hline Rural drainage & 5 & 2 & 8 & 2 & 72 & 22 \\
\hline Outflow & 18 & 31 & 50 & 61 & 335 & 496 \\
\hline
\end{tabular}


This indicates that currently there is good leaching and suggests that even a slight change in the salt retention in the soil caused by changing irrigation practices could cause adverse impacts on crop production.

\section{DISCUSSION}

At most locations in the river, the lowest salt concentrations occur in August, when river flows are high, while the highest concentrations are in April, when river flows are low (Fig. 4). Within the city this seasonal variation can be attributed primarily to lack of inflow from upstream and reduced dilution of wastewater in the dry season. Downstream, the increase in salinity even in April can be attributed to saline return flows from the irrigated fields. On average, over the year, 9\% of TDS at Bhattaguda (point VIII) can be attributed to processes (evaporative concentration) downstream of the city limits at Peerzadiguda (point III). The largest proportional increase occurred in July when $21 \%$ of TDS at Bhattaguda occurred as a consequence of evaporative concentration downstream of the city. In April and August it is $3 \%$ and $2 \%$ respectively.

The hypothesis that the increased salinity between Peerzadiguda and Bhattaguda might be a consequence of evaporation from the river surface, particularly from the reservoirs formed behind the weirs was tested. Assuming an annual open water evaporation of $1,583 \mathrm{~mm}$ (based on 0.7 of the Apan evaporation for the city) and average width of the river of $100 \mathrm{~m}$ (which includes an allowance for the width of the reservoirs) over a distance of $30,100 \mathrm{~m}$ gives an annual evaporation of $4.8 \mathrm{Mm}$ This corresponds to an increase in TDS of $1.3 \mathrm{mg}$ $\mathrm{l}^{-1}$ compared with an observed increase of $133 \mathrm{mg}$ $1^{-1}$ between sample points III and VIII. Thus, at most, open water evaporation from the reservoirs accounts for just $1 \%$ of the observed increase. This result is not surprising given the large difference in the area irrigated compared to the surface area of the river.

The sustainable use of saline water in irrigation requires control of soil salinity at the field level (Beltran, 1999). Currently, in many fields irrigated with wastewater from the Musi River, soil salinity levels are significantly above the recommended salinity threshold for rice $\left(1.9 \mathrm{dSm}^{-1}\right)$. Although it is likely that other socio-economic factors may be contributing to the change, farmer adaptation to increased soil salinities does provide one plausible explanation for the switch from rice to paragrass.
A similar shift to fodder grass has occurred in wastewater irrigated areas in the vicinity of Cochabamba, Bolovia, where it has also been attributed to soil salinization (Huibers et al., 2004). In those fields with the highest salinity levels (in excess of $10 \mathrm{dSm}^{-1}$ ) it is possible that even paragrass yields may be adversely affected in the not too distant future. The salinity levels are lower further from the city but even at Bhattaguda it is possible that rice yields are being reduced. In some places the farmers maintain yields by mixing wastewater and groundwater or by alternating wastewater and groundwater use (Buechler and Mekala, 2005).

The analyses presented in this paper are a preliminary assessment. The scarcity of data means that the results are indicative; as discussed above, the calculations depended on a number of assumptions. To improve estimates of the salt and water fluxes, further monitoring is required. This should include: i) determination of the temporal variation in the volumes and salinity of wastewater discharged, as well as rural flows, entering the river downstream of Amberpet Bridge, ii) measurement of the flow in the river at key sampling points, particularly Bhattaguda, iii) more exact determination of the volume of irrigation diversions, iv) systematic measurement of the concentration of different elements present in the irrigation water, v) identification of saline inflows causing the salinity increase observed at Bhattaguda, and vi) monitoring of the flow bypassing Bhattaguda.

\section{CONCLUSION}

Appropriate water resource planning and management at the catchment scale requires consideration of the full water cycle including disposal and use of wastewater. Furthermore, sustainable use of wastewater for irrigation requires careful consideration of not only the health impacts but also the environmental impacts, including short- to long-term effects on the salinity of soils and river water. Whether wastewater irrigation results in significant environmental degradation and/or declining crop yields depends on contextual determinants, including the salinity of the water, the extent of irrigation and soil characteristics. The current study indicates that in the Musi River catchment, salinity is likely to be a contributing factor to the poor ecological condition of the river and is likely to be the cause for farmers switching from rice to paragrass. It is anticipated that as the population of Hyderabad rises, wastewater irrigation will 
increase in the immediate future. Long-term flow and water quality monitoring is essential to enable the informed decision-making required to maximize the benefits and mitigate both the human health and environmental risks.

\section{ACKNOWLEDGEMENTS}

The authors thank Liaquat Ullah, Urmila Matha and Mohammed Quadeer for assistance with sampling. They also wish to thank Stephanie Buechler and Gayathri Devi for providing background information and literature.

Matthew McCartney acknowledges the late Dr. F. P. Amerasinghe for his outstanding mentoring as part of IWMIs Leadership Development Program and his encouragement to undertake this study.

\section{REFERENCES}

Beltran, J.M. (1999). Irrigation with saline water: benefits and environmental impacts. Agricultural Water Management 40: 183-194.

Buechler, S. and Mekala, D. G. (2005). Local Responses to Water Resource Degradation in India: Groundwater Farmer Innovations and the Reversal of Knowledge Flows. Journal of Environment and Development 14 (4): 410-438.

Buechler, S., Devi, G. and Devi, R. (2003). Making a living along the Musi River. Wastewater users in and around Hyderabad City, India. Video.

Buechler, S., Devi, G. and Raschid, L. (2002). Livelihoods and wastewater irrigated agriculture along the Musi River in Hyderabad City, Andrha Pradesh India. RUAF Magazine 8: 12.

Cooper, R.C. (1991). Public health concerns in wastewater reuse. Water Science and Technology 24(9): 55-65.

Dickens, C.W.S. and Graham, P.M. (1998). Biomonitoring for effective management of wastewater discharges and the health of the river environment. Aquatic Ecosystem Health and Management 1: 199-217.

Ensink, J.H.J. (2006). Wastewater quality and the risk of hookworm infection in Pakistan and Indian sewage farmers. Ph. D. Thesis, University of London.
Gosain, A.K., Rao, S., Srinivasan, R. and Reddy, N.G. (2005). Return-flow assessment for irrigation command in the Palleru river basin using SWAT model. Hydrological Processes 19: 673-682.

Gerwe, C. (2004). An assessment of heavy metals contamination in the wastewater irrigated area of the Musi River. IWMI Report. Pp. 62.

Grattan, S.R. (2002). Irrigation water salinity and crop production. University of California, Publication No. 8066. Pp. 9.

Hart, B.T., Bailey, P. Edwards, R., Hortle, K., James, K., McMahon, A., Meredith, C. and Swaling, K. (1991). A review of the salt sensitivity of the Australian freshwater biota. Hydrobiologia, 210: 105-144.

Hoffman, G.J., Ayers, R.S., Doering, E.J., and McNeal, B.L (1981). Salinity in irrigated agriculture. In Jensen, M.E. (Ed) ASAE Monograph.

Huibers, F.P., Moscoso, O., Durán A. and van Lier, J.B. (2004). The use of wastewater in Cochambamba, Bolivia: a degrading environment. In Scott, C.A., Faruqui, N.I. and Raschid-Sally, L. (Eds) 2004. Wastewater use in irrigated agriculture: confronting the livelihood and environmental realities. $\mathrm{CAB}$ International Publishing, Wallingford. Pp. 135-144.

James, A.J. and Robinson, E. (2001). Water and sustainable rural livelihoods in Andhra Pradesh: Background Paper. WHIRL Project Working Paper Pp. 70 .

James, L.G. (1988). Principles of farm irrigation system design. John Wiley and Sons, New York. Pp. 54

Katta, M.R. (1997). Predatory industrialisation and environmental degradation: a case study of the Musi River. Telangana: Dimensions of Underdevelopment, Centre for Telangana studies, Hyderabad, India. Pp. 203-212

Kijne, J.W. (2003). Water productivity under saline conditions. In: Kijne, J.W., Barker, R. and Molden, D. (Eds) Water productivity in agriculture: limits and opportunities for improvement. CAB International. Wallingford, UK Pp. 89-102.

Paroda, R.S. (1998). Inaugral address. In Gupta, S.K., Sharma, S.K. and Tyagi, N.K. (Eds). Salinity management in agriculture. Proceedings of the 
National Conference, December 2-5, 1998. Central Soil Salinity Research Institute, Karnal, India. Pp. 4-6.

Pescod, M. D. (1992): Wastewater treatment and use in agriculture. Food and Agricultural Organization. Rome, Italy.

Peterson, M.S. and Meador, M.R. (1994). Effects of salinity on freshwater fishes in coastal plain drainages in the Southeastern US. Reviews in Fisheries Science 2: 95-121.

Priestley, C.H.B. and Taylor, R.J. (1972). On the assessment of surface heat flux and evaporation using large scale parameters. Monthly Weather Review 100: 81-92.

Scott, C.A., Faruqui, N.I. and Raschid-Sally, L. (Eds) 2004. Wastewater use in irrigated agriculture: confronting the livelihood and environmental realities. $\mathrm{CAB}$ International Publishing, Wallingford. Pp. 9.

Schwab, G.O., Fangmeier, D., Elliot, W.J. and Frevert, R.K. (1993). Soil and water conservation engineering. John Wiley and Sons, New York. Pp. 507.
Shaw, E. (1984). Hydrology in practice. Van Nostrand Reinhold (UK) Co. Ltd. Wokingham. Pp. 569.

Tanji, K.K. and Kielen, N.C. (2002). Agricultural drainage water management in arid and semi-arid areas. FAO Irrigation and drainage Paper 61. Food and Agricultural Organization of the United Nations, Rome.

United Nations (UN) (2002). World urbanization prospects, the 2001 revision. United Nations, New York, USA.

Van Roojen, D., Turral, H. and Biggs, T.W. (2005). Sponge city: water balance of mega-city water use and wastewater use in Hyderabad, India. Irrigation and Drainage 54: S81-S91.

World Health Organization (WHO) (2006).

Guidelines for the safe use of wastewater, excreta and greywater. Vol. 2 Wastewater use in Agriculture, WHO, Geneva.

Zeng, L., Shannon, M.C. and Lesch, S.M. (2001). Timing of salinity stress affects rice growth and yield components. Agricultural Water Management 48: 191-206. 